Summer 2005

\title{
American Constitutional Fantasies: Escape from Difference Through Escape from Government
}

David C. Williams

Indiana University Maurer School of Law, dacwilli@indiana.edu

Follow this and additional works at: https://www.repository.law.indiana.edu/ijgls

Part of the Constitutional Law Commons, International Law Commons, and the Legislation Commons

\section{Recommended Citation}

Williams, David C. (2005) "American Constitutional Fantasies: Escape from Difference Through Escape from Government," Indiana Journal of Global Legal Studies: Vol. 12 : Iss. 2 , Article 4.

Available at: https://www.repository.law.indiana.edu/ijgls/vol12/iss2/4

This Symposium is brought to you for free and open access by the Law School Journals at Digital Repository @ Maurer Law. It has been accepted for inclusion in Indiana Journal of Global Legal Studies by an authorized editor of Digital Repository @ Maurer Law. For more information, please contact rvaughan@indiana.edu.

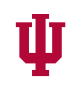

JEROME HALL LAW LIBRARY

INDIANA UNIVERSITY

Maurer School of Law
Bloomington 


\title{
American Constitutional Fantasies: Escape from Difference Through Escape from Government
}

\author{
David C. Williams*
}

One of the delights of comparative legal work is coming to understand the way that different legal traditions offer quite different answers to the same questions. Perhaps an even greater joy is discovering that not only do different legal traditions have different answers, they also find quite different questions to be central and pressing. This conference, at which Americans and Europeans meet, is organized around the question, "Back to Government? The Pluralistic Deficit in Decisionmaking Processes and Before the Courts." In Europe, where this conference has been organized and is occurring, this question has powerful resonance. Some have the sense that in Europe, both within the Member States and the European Union (EU) itself, some degree of power has shifted from government to governance. For the Americans, I should perhaps explain that government in this formulation refers to the formal channels of governmental institutions; governance has a somewhat more vague and contested meaning, but it generally refers to legal and political mechanisms that people have developed to advance their interests and values outside of the formal channels of government-such as lobbying and privatization. In Europe, this field of governance is conceived as a tertium quid, in neither the government nor the private sphere. People have looked to governance to protect their interests when the government seems to be seized by a small group of powerful interests. Governance, however, suffers from its own accountability problems, and so the conference organizers wonder whether it is time to go back to government. In fact, Europeans may approach this question from a particular historical perspective: we have tried so hard to understand and develop the field of governance, these Europeans may think, but it has not worked, so is it at last time to ponder the possibility of rehabilitating government?

In the United States, this question does not have anything like the same resonance; in fact, it might be argued that the question has no resonance at all be-

* John S. Hastings Professor of Law, Director, Center for Constitutional Democracy in Plural Societies, Indiana University School of Law-Bloomington; J.D., Harvard Law School; B.A. Haverford College. 
cause it presupposes a set of categories and issues quite different from those that currently dominate the American legal and political horizons. To speak of going back to government implies that we were once there and are now returning, perhaps going home or to an old friend or familiar territory. In fact, some of the organizers of this conference have suggested that sometimes they feel nostalgic for government. But for Americans the title might better be "Still Getting To Government," because we never really got there in the first place. Many, perhaps most, Americans tend to imagine government as an artificial creation with shallow roots and doubtful legitimacy, so they want to protect themselves from its reach. These days, we Americans hear very little about the good that government can do, and we hear a great deal about how we might roll it back. In Europe, people divide the world tripartite into government, governance, and citizens, with complicated and contested relations between the three; but in America, people divide the world simply between the public and the private, with a pronounced preference for the latter over the former. Indeed, in this view, the line between the public and the private must be kept quite sharp, without the confusing "governance" category, so as to keep the government within bounds, away from the private sphere. The closest analogue that we might have to governance is civil society, but again we imagine that concept as private persons voluntarily associated to check and control government, not as some intermediate element. In short, then, we can imagine that a fairly typical American, when asked to think about going "Back to Government," might observe: "Back to Government? We were never really there! And thank God!"

To understand why Americans have such a different reaction to the question posed by this conference, we must examine certain foundational legal ideas and stories; these are legal myths, if you will, in the sense of being fundamental conceptual structures that explain the world, not of being fictions or superstitions (though some may find them to be so). Before I offer my thesis in a more rigorous way, some qualifications and explanations are appropriate. Some people prefer legal work that dwells only on the concrete and close-to-theground: data that you can count and code provisions that you can cite. My own view is that a country's legal system, taken in the main, grows from its foundational myths. To understand the differences between different legal systems, therefore, one must understand the differences between these myths. If we do not engage in this kind of comparative analysis, we will never come to understand the other, the path not taken, and the possibilities that may still be available. Inevitably, however, mythic analysis has a certain gauziness when compared to the 
parsing of codes. My discussion will necessarily be general; not all Americans adhere to the myths that I will describe, and even the adherents differ in their zeal; and in a compass as short as this essay, I will be able to offer only a few illustrative examples. Nonetheless, I feel that most Americans will recognize instantly the mythic landscape that I will map; and in the very same landscape, most Europeans may feel like strangers wandering in a strange land. And that difference speaks volumes.

To help explore these diverging perceptions, let me first elaborate the thesis on which this conference has been based by its European organizers, and then I will suggest some of the difficulties in trying to understand that thesis in an American context. Here is the thesis of the conference as I understand it. Many in Europe are unhappy with the EU because they think it insufficiently pluralist; that is, it underrepresents the interests of certain groups. So, for that matter, do the national governments of Europe. So Europe is suffering from a broad pluralistic deficit in government. As a result, some citizens have developed new mechanisms to protect and advance their interests. In the language of the conference description, these devices do not "imitate" the "traditional forms of participation." Instead, they have looked outside the formal legal framework for "alternative or additional channels shaped according to a different rationale, namely privileging the functional rather than political representation of their interests." Some of these devices involve finding ways to influence government decisionmaking outside the formal process - such as lobbying and the like. Other mechanisms involve attempts to bypass the legislative process altogether, such as privatization and "soft" law. The goal of these devices is to remedy the pluralistic deficit in government by finding routes outside government's formal structure. The problem with these devices, however, is that they are unaccountable to the general public, so we must wonder whether it is time to go "Back to Government." Perhaps there is a way to take what is best about these devices-their ability to raise voices that have been under-consulted - and then incorporate them into a structure of government that is broadly accountable to all. The conference organizers hope that the American experience might shed some light on this possibility for two reasons. First, American constitutionalism has pluralism built into its very physiognomy. Second, the U.S. Supreme Court is notably willing to give the Constitution a flexible and evolutionary interpretation, so that the justices might find a way to incorporate these new devices into the structure of governance - taking them "Back to Government." In this view, Europe might 
be able to learn something from the United States about the challenge of combining pluralist governance with accountable government.

My response to this thesis is threefold. First, I accept as given the conference's description of the situation in Europe; my goal here is not to try to explain Europe to Europeans but to reflect on European questions from an American perspective. Second, I agree that American constitutional governance has a degree of pluralism built into its physiognomy. Private power in America has rarely been broadly distributed; in that sense, the private sphere suffers from a pluralistic deficit. In response, American government has often extended its reach to correct these private power inequalities. Third, at a mythic level, the drive to go outside government in America grows largely out of a desire to deny governmental pluralism, not to remedy a pluralistic deficit in government, which has after all been more pluralist than the market or similar private ordering mechanisms. Although the road to government has offered a chance at real power-sharing, Americans have always been reluctant to move down that road, because they fear its destination. Instead, they like to imagine that there is a social realm outside of or beyond government in which we are all the same, at least in the ways that matter. In this sphere, because we share an identity of interest, we do not need to worry about pluralist power-sharing or even the messiness of politics. Few Americans want to eliminate government, but most want to escape it to the extent possible into this realm beyond government, which they imagine as more natural. In this view, if we get off the road to government, we can escape difference, so that we will not need government after all. As a result, I fear that the American experience has little to offer Europe. If we were to bring American extra-governmental devices "Back to Government," they would not remedy the pluralistic deficit in government, because they represent a desire to escape pluralism, not celebrate it.

\section{American Governmental Pluralism}

My first claim about the United States is that U.S. constitutionalism and U.S. government in general have offered Americans the possibility of real pluralism. From the beginning, our constitution sought to give formal representation to a plurality of different groups, considered as groups. For example, we have federalism because many people thought that the different states had different collective interests. Each state therefore retains some control over its own affairs, immune from federal control. In the federal government itself, each 
state, regardless of population, elects two senators, so that the smaller states have as much protection for their interests as the larger states do for theirs. ${ }^{1}$ Originally, the state legislatures elected U.S. Senators, ${ }^{2}$ so it was clear that senators were supposed to represent states as states, not as collections of diverse individuals. Even now, when senators are directly elected, ${ }^{3}$ most still imagine their jobs as representing the collective interests of a state citizenry.

In this view, then, the Senate should protect states as such. Some leaders offered a slightly different rationale for the Senate: the Senate and the House of Representatives would represent different social orders. In particular, because Senators are elected from large areas for long terms, many thought that the Senate would be dominated by men of wealth, education, and prominence. ${ }^{4}$ The House, by contrast, would be full of ordinary people, the demos, the hoi polloi. With this division in mind, the Constitution gives senators, with their presumed sagacity, the power to approve treaties; ${ }^{5}$ and the House, with its concern for the people's pocketbooks, the exclusive power to initiate appropriations bills. ${ }^{6}$ So we have two theories for the existence of the Senate-it was supposed to represent states as states, and it was supposed to represent the elite as the elite-but what the theories have in common is that in both, the Constitution formally allocates power to groups that otherwise might have too little voice.

More recently, people have worried less about protecting small states or men of property; instead, legal reformers have been more concerned about allocating political power to racial, ethnic, religious, and gender groups. This concern animates a great deal of recent constitutional politics, and I cannot fully summarize these developments in this limited compass. Instead, let me offer one example that illustrates the more general phenomenon. In the United States, for a long time, many states limited the right to vote in such a way as to disenfranchise most of the African-American population. Before the Civil War, these limits were overtly racial: only Whites were allowed to vote. After the war, the limits on the right to vote were overtly neutral — devices such as literacy tests, good character requirements

1. See, e.g., The Federalist No. 62, at 365 (James Madison or Alexander Hamilton) (Isaac Kramnick ed., 1987).

2. See U.S. Const. art. I, § 3, cl. 1, amended by U.S. Const. amend. XVII, § 1.

3. See U.S. Const. amend. XVII.

4. See, e.g., Gordon S. Wood, The Creation of the American Republic: 1776-1787, at 55357 (1972).

5. See, e.g., The Federalist No. 64, at 375-77 (John Jay) (Isaac Kramnick ed., 1987).

6. See U.S. Const. art I, $\$ 7$, cl. I. 
and the like-but they were administered in such a way as to disenfranchise the bulk of the Black population. Eventually, the Supreme Court and the Voting Rights Act of $1965^{7}$ eliminated most of those restrictions, and Black voting rates soared. As a result, many commentators confidently anticipated that AfricanAmericans would receive their fair share of electoral power. ${ }^{8}$

But that did not happen because of the structure of our electoral system. Remember that American elections occur in single-member districts, where the winner takes all. In the great majority of districts, racial minorities are in the minority, so they cannot control the election of their representative. Because these are winner-take-all affairs, the losers send no one to the legislature; they simply lose. Now, if racial minorities cannot control the election in their district, and if they believe that they have systematically different interests from the majority, then they may feel effectively disenfranchised by this system. Suppose for a moment that a racial group comprises 20 percent of the population of a state but forms a majority in only 2 percent of the districts. As a result, though comprising 20 percent of the voters, they control only 2 percent of the legislature. Even if all these voters are registered and turn out on election day, they may feel that government has failed to give them their appropriate share of power.

What I have described is not a hypothetical situation. All across the United States, for a very long time, Black and Hispanic voters controlled a much smaller fraction of the legislature than their numbers would appear to warrant. In the language of the conference, we might call this a "pluralistic deficit" in government. But minority voters did not turn away from government. Instead, they asked government to reform itself by establishing what are called majority minority districts: these are winner-take-all, single-member districts that are deliberately drawn so that minorities make up a majority of the voters in them. If you create enough of these districts, even within our electoral system, minorities might eventually command something like their proportional share of the legislature.

Minority voters first asked for such districts before the U.S. Supreme Court, and for a while, the Court held that under some circumstances, the Constitution guaranteed these voters a right to majority minority districts. ${ }^{9}$ According to the

7. 42 U.S.C. § 1973 (2000) (amended 1970, 1982).

8. See Samuel Issacharoff et al., The Law of Democracy: Legal Structure of the PolitiCal Process 90-129 (rev. 2d ed. 2002).

9. See White v. Regester, 412 U.S. 755 (1973) (affirming the disestablishment of multi-member congressional districts in Texas based on a finding that they diluted minority voting power). 
complainants in these cases, the right to vote means something only if the voter is grouped with like-minded voters; if instead the voter is submerged in a sea of contrary-minded voters, then his vote has been diluted. But after recognizing such claims for a time, the Court eventually backed away: it held instead that voters have no constitutional right to be grouped with people like themselves. Instead, legislatures are required only to draw district boundaries without a deliberate intent to hurt a racial group. ${ }^{10}$ But suppose that legislatures have no such intent, and they draw a districting scheme in which, by happenstance, a racial minority with 20 percent of the voters controls only 2 percent of the districts. This racial minority still feels powerless, but according to the Supreme Court, there is no constitutional violation because the legislature has not intended to discriminate against them.

In the early 1980s this problem fell into the lap of that most political branch, the U.S. Congress. Astoundingly, Congress decided to reform itself by amending the Voting Rights Act (VRA) to require the states sometimes to draw majority minority districts." For those who completely distrust government, it is worth recalling that these politicians in Congress passed a statute that would inevitably diminish their own chances of reelection. The VRA amendments required redistricting, which would alter the constituencies that put the incumbents in office, which, in turn, would imperil the political future of these incumbents. And yet these same incumbents overwhelmingly voted for it. So the legislature saw a pluralistic deficit in itself, and then the legislators did something to remedy it, even at the cost of undermining their own power.

The U.S. Supreme Court's current interpretation of the VRA is roughly as follows: to have the right to a majority minority district, a group of minority voters must show: (1) they have traditionally voted as a bloc, suggesting that they perceive their electoral interests in racial terms; (2) the majority voters in their area have traditionally voted in a racially polarized way, meaning at least that they have voted for candidates other than those favored by the minority voters; (3) residentially, the minority voters are settled closely enough together that the legislature could draw a compact, contiguous district in which they would form a majority; and (4) the minority voters in a given state have less than proportional representation, meaning that the fraction of districts that they control is lower than the fraction of the electorate that they represent. ${ }^{12}$ It is difficult to sat-

10. See City of Mobile v. Bolden, 446 U.S. 55, 66 (1980).

11. See 42 U.S.C. § 1973(b); IssacharofF et AL., supra note 8, at 713-45.

12. See, e.g., Johnson v. DeGrandy, 512 U.S. 997 (1994). 
isfy these requirements, and so there are not very many majority minority districts. Today, racial minorities still control a smaller share of the districts than their share of the electorate. In that sense, they are still underrepresented.

And now the action returns to the Supreme Court. When last we left the Court, they had just held that the Constitution does not require majority minority districts. Now that Congress has statutorily required some such districts, the Court has decided that the Constitution actually forbids them, at least when race is the "predominant factor" in their creation. ${ }^{13}$ For a while, it even looked as though the Court might outlaw intentional majority minority districts altogether, but the latest cases indicate that they will be allowed in limited circumstances. ${ }^{14}$

Here is the upshot of this tale: the American legislature is clearly suffering from a pluralistic deficit on the issue of race. Racial minorities have repeatedly asked for more effective representation, but they have been given relatively little. And yet despite this history, America's racial minorities are convinced that government is the answer, not the problem. They remain committed to reforming government, not going outside it. The reason for this enduring faith is that government has offered the only real possibility of power-sharing for them. The private sphere-the realm of extra-governmental devices-has always seemed far more threatening. African-Americans keenly recall that the Ku Klux Klan, with its determination to stop Black voting, grew up in the private realm, not in government, and Blacks achieved voting rights only through agitation within government, not informal channels.

If American Blacks remain committed to government, however, many others have become thoroughly disgusted with it. These people believe that government has become excessively solicitous toward "special interests," a term used to refer to women; racial, linguistic, ethnic, and religious minorities; gays, lesbians, and bisexuals; the disabled; and many others-in other words, the great bulk of the American citizenry that does not resemble that "average" American, the straight, White, able-bodied, taxpaying male. In this view, government has become too pluralistic, the instrument of powerful factions that ruthlessly seek to advance their own agenda, and politics has become an ugly game of rent-seeking. In this indictment, one of the primary bits of evidence is

13. See, e.g., Shaw v. Reno, 509 U.S. 630 (1993); Miller v. Johnson, 515 U.S. 900 (1995). Shaw initiated this line of cases; Miller created the "predominant cause" test.

14. See Easley v. Cromartie, 532 U.S. 234 (2001) (holding that majority minority districts are permissible if the predominant factor in drawing the district is political affiliation, not race). 
the existence of the majority minority districts themselves, which in this view, aim not at fairness but at maximizing minority power, whatever the cost. They involve a kind of reverse gerrymandering to shore up Black might. As a result, they encourage racial divisiveness by encouraging both majority and minorities to conceive of their interests in racial terms. ${ }^{15}$ And so government has become hostage to the politically correct doctrine of structural pluralism. Ergo, those who want simple fairness have no option but to develop mechanisms outside government that will allow them more functionally to pursue their interests.

\section{The Road Away From Government}

We have come now to my second claim about the United States. The turn away from government in the United States grows substantially out of a desire for less pluralism, not more. Because I am surveying a large development, my argument will necessarily become sketchier. I will inevitably over-generalize: after all, Americans have developed a whole variety of extra-governmental devices, for a whole variety of reasons. Many of those devices do not fit the description that I am about to offer. Nonetheless, amidst all this variety, we should not miss the forest for the trees: to a significant extent, the American desire to escape the formal governmental structure has its roots in a traditional set of antigovernment attitudes. In my own view, these attitudes, in more or less intense form, approach an orthodoxy. But even if they are not truly ubiquitous, they clearly fuel much of the current dis-

15. For an example, we need look no further than the Supreme Court itself:

We have acted on the implicit assumption that members of racial and ethnic groups must all think alike on important matters of public policy and must have their own "minority preferred" representatives holding seats in elected bodies if they are to be considered represented at all.

-....

.. We have involved the federal courts, and indeed the Nation, in the enterprise of systematically dividing the country into electoral districts along racial lines-an enterprise of segregating the races into political homelands that amounts, in truth, to nothing short of a system of "political apartheid." ...

... The assumptions upon which our vote dilution decisions have been based should be repugnant to any nation that strives for the ideal of a color-blind Constitution....

... [F] ew devices could be better designed to exacerbate racial tensions than the consciously segregated districting system currently being constructed in the name of the Voting Rights Act.

..."We are bent upon polarizing political subdivisions by race."

Holder v. Hall, 512 U.S. 874, 903-07 (1994) (Thomas, J., concurring). 
satisfaction with the way that government conducts its business. When Europeans contemplate American strategies, they must reckon with this mindset, despite its unfamiliarity to them.

As in Europe, many Americans think that government fails adequately to represent their interests, and so they have had to look elsewhere. But American reasons for moving away from government are importantly different from the European reasons highlighted by the conference organizers. As described in the statement of the conference, Europeans have moved away from government for basically instrumental reasons. They perceive a limited problem in governmenta pluralistic deficit-and in response they develop limited mechanisms to find a greater pluralism outside government. In the United States, by contrast, the extragovernmental impulse grows out of a broad ideology that casts the entire legitimacy of government into doubt. Its goal is not merely to supplement government but somehow to escape it. It represents a hope to transcend the bickering pluralism of American politics into a metaphysically better condition, a harmony achieved without governmental meddling. Most commonly, the extra-governmental devices aim not at making government more pluralistic, but at limiting the reach of government altogether.

To understand this impulse, we must sketch a basic mindset that underlies much of U.S. constitutional law and politics. In this view, government is neither natural nor ancient. Instead, it is a relatively recent and artificial creation, designed by individuals simply to protect their personal rights. In this vein, many conceive of the U.S. Constitution as a social contract that created America; before that, we were a loose assembly of states, or communities, or even individuals. We have decided to give government a chance, to see how it will turn out. But we always remember that once we made do without it; that if government fails to live up to its charge, we can still jettison it; that even now, government must live under severe restrictions designed to protect the private sphere; and that the private sphere is not the product of government or even of civil society, but rather is the vestige of a better, freer, more harmonious, aboriginal state of being. When many Americans contemplate going outside government, therefore, they are not merely looking for devices to correct a structural problem in government; they are seeking to keep alive a prelapsarian world, with roots in the time before we accepted the messy necessity of government.

In this mindset, the social contract is believed to be a historical event, not just a metaphor or a heuristic that allows us to examine the relationship between governors and governed. The Founders agreed to certain terms in the contract, 
and those particular terms, the actual words of the Constitution (and not some philosophical abstraction) give the government its sole authority. But because this contract is only a historical fact, it is also only a historical trial, because the signatories-the citizens of America-can always renounce it in whole or in part. In fact, many wish that it would be undone, to the extent possible, so as to preserve our primordial freedom.

The dangers in this sort of thinking are obvious. I have suggested that government has offered America's best prospect for pluralist power-sharing. Even Locke acknowledged that a world without government was not only unthinkable but highly undesirable. ${ }^{16}$ How can these Americans then yearn for a world without government? Do they realize that without government, there is no accountable structure to allow different groups to live together, no rules of the game to keep us from each other's throats? Do they realize that the strong will dominate the weak? It is tempting to suggest that some antigovernment Americans do realize all those things. Surely some contemplate that without government, the strong will dominate the weak, but they imagine themselves as the strong. Many of those seeking to escape government have more money and/or more guns than the norm, so it may be rational to imagine that less government means more power for them.

But Americans are seldom so cynical, or at least so open, about the brute fact of power. Even when we are really seeking our own gain, we try to describe it in terms of a universal good. And so when antigovernment Americans talk about a world without (or with less) government, they do not suggest that somethose with guns or money-will dominate others. Instead, they imagine that our differences will vanish, so no one will dominate anyone. We will suddenly see that pluralism was only a phantom, foisted on us by manipulative politicians. Really, we are all the same underneath, but we will come fully to that realization only when we escape government. Hence my title, American Constitutional Fantasies: Escape from Difference Through Escape from Government.

\section{Constitutional Fantasies}

A number of such fantasies command adherents in America today. Again, space does not allow a full review, but to give a flavor, let me sketch two, perhaps

16. See John Locke, The Second Treatise of Government, in Two Treatises of Government III 123-31, at 368-71 (Peter Laslett ed., Cambridge Univ. Press 1960) (1690). 
the two most important fantasies. We might call these the Populist Fantasy and the Libertarian Fantasy. ${ }^{17}$ Again, qualifications are in order: I do not mean that all populists or libertarians subscribe to these fantasies, nor that all populist and libertarian thinking is fantastical. Instead, I mean that much antigovernment thought in America has its roots in these two fantasies, and in that respect, America is significantly different from Europe.

The Populist Fantasy imagines that America was born in a moment of great unity, when a single people sat down and wrote out a social contract appropriate to itself. This People acts as a single, organic entity, and it should be capitalized, as befits a proper noun. In the decades since the Founding, however, the American "People" has lost its unity: the citizens have fallen into pluralist squabbling as interest groups, ethnic communities, political parties, and so forth. The People is no longer a singular noun, as it is now achingly plural and pluralist.

This story of decline and fall helps populist fantasists to recognize the present fact of pluralism without letting it threaten their claim that "real" Americans still form an organic entity. Remember that fantasists of this stripe imagine that, at all important moments, the American People has acted with unity. America was born from a social contract to which individuals, families, and communities spontaneously agreed. Even before it sat down to write this contract, the American People had risen up against the British Empire in a spontaneous revolutionary movement, unified but outside the structure of government. Today, if America's revolutionary heritage is to remain alive, America must be led by a group of people who still stand for the Framers' values-a saving remnant that represents the American People in its original organic unity. This group, the Real American People, retains the right to depose government, take power back into its own hands, and institute a new government founded on the consent of the governed. In all of these cases, the fantasists imagine the American People acting in great unity, but without a governmental frame to help them resolve their differences. How is this possible? Certainly, modern Americans in their diversity could not accomplish such magical coherence. But here is where the fantasy comes to the rescue: perhaps Americans are not now so unified, but most of these modern Americans are fallen and sinful. Once upon a

17. See David C. Williams, The Mythic Meanings of the Second Amendment: Taming Political Violence in a Constitutional Republic 151-257 (2003) (surveying these fantasies, especially the ones that involve the possibility of political violence). In the following several pages of the text of this article, I merely summarize material that I lay out in some detail in the book. 
time, the American People acted as one body-the "Body of the People"-and to this day, some Americans can still claim descent from the founding entity. Those Real Americans must stay vigilant, scrutinize the government, and be ready to overthrow it for the good of the People.

This story of decline offers a great psychic benefit to its authors. If you really imagine that government is temporary, contingent, and dispensable, then you must imagine an alternative. But at first glance, it seems plain that removing government from America would reduce us to a bloody war of all against all, in which life is nasty, brutish, and short. This fantasy, however, promises us that it need not be so. Historically, in this view, the American People was once united, and it can be so again. It can therefore threaten government not with suicidal civil war, but with a united uprising. The possibility of escaping difference by escaping government into a mystically unified campaign of violence is still alive and well, and the birthright of every American child. In short, we need not reconcile ourselves to the inevitability of government and pluralism.

One version of this populist fantasy is savagely ethno-nationalist, and it shares much with European fascism. In this view, the Real American People has always included only those of a certain racial, religious, ethnic, cultural, or political background. At its most malignant, this version insists that only White, male, conservative, heterosexual, anti-communist, gun-owning, Protestants can really be members of the American Volk. People of this sort-Real Americans-made America the greatest nation on earth, only to see it taken over by immigrants and traitors. But these Americans are still united in the spirit of the Volk, and soon they will have to take back their country from the villains in Washington. At its most extreme, this rhetoric is limited to the truly radical right, which does not have a lot of power. But in less extreme ways, this mindset clearly underlies the thinking of more mainstream figures like Charlton Heston, the former president of the $\mathrm{Na}$ tional Rifle Association, and presidential candidate Pat Buchanan, who famously urged his fellow Americans to take "back [their] cities, and take back [their] culture, and take back [their] country" from people like inner-city rioters. ${ }^{18}$

Still, not too many Americans would openly endorse this ethno-nationalist fantasy of escape from difference. But the Populist Fantasy sometimes shades over

18. Buchanan offered this advice at the 1992 Republican National Convention, on national television and to wild applause from the conventioneers. See Pat Buchanan, Speech at the $1992 \mathrm{Re}$ publican National Convention (Aug. 17, 1992), at http://www.buchanan.org/pa-92-0817-rnc.html (last visited Feb. 28, 2005). 
into a Libertarian Fantasy that is much more widely shared. Let us return to this puzzle of the social contract: without benefit of government, the people somehow cohered as individuals to make a government. Without any real political structure, plunged into the state of nature by the War for Independence, they somehow magically agreed on a single set of contractual terms, a single plan for making a government and a country. But how likely is this occurrence? How plausible is this story? The populists insist that spontaneous agreement was possible because of the ethno-nationalist unity of the American people: they are really one. The libertarians, by contrast, insist that it was possible because every individual signatory to the contract regarded himself purely as an abstract individual, without distinguishing social identity. At root, everyone is basically the same: not men or women; Black or White; Muslim or Christian; rich or poor; but just individuals. These abstractions possess only two characteristics: will and reason. Ergo, they define themselves by their choices, and the government's only role is to defend their autonomy. And so we arrive at a libertarian theory of government.

Let us now reimagine the moment that the American people created the social contract. The populists insist that at this instant the American Volk came together and found itself united by a single spirit. By contrast, libertarians maintain that American individuals realized that they were all the same, precisely in that they were not a Volk but merely generic individuals. They were all essentially alike in being disconnected atoms, with a desire to be treated as such. Though individuals, they all want the freedom to individuate their lives, to pursue their own view of the good. And so, most fundamentally, they are not really different individuals at all; they are really the same metaphysical person, with the same rights, faculties, and basic desires, endlessly iterated in different bodies. And because they are really generic individuals, they could agree on a generic set of contractual terms.

Centrally, the libertarian contract will require government to treat people as abstract and autonomous choosers, with the right to pursue their own separate goals. Libertarians commonly argue that the Constitution should be interpreted through a libertarian lens. If the social contractors wanted to be regarded as abstract individuals, then it stands to reason that they mostly wanted to protect their right to do as they liked until they invaded someone else's liberty. This constitution celebrates individualism, but it is distinctly uneasy with the real world differences-in culture, language, race, and so forth-that pluralism celebrates. In fact, this libertarian constitution insists that government may never legitimately recognize these differences; instead, government must always treat everyone as abstract individuals, devoid of particular identity. 
Examples of this mindset could be endlessly accumulated, but to little point, as they are familiar to every American. ${ }^{19}$ Because we began with majority minority districts, let us return to them as our example. Because they know that the issue of race is alive and well in America, many minority voters conceive of their political interests in racial terms. For their votes to be powerful, these voters want to be districted with similar voters, so that they can control the election of a representative to the legislature. Under the Voting Rights Act, in fact, minority voters are entitled to a majority minority district only when they can show that they vote as a bloc, and majority voters tend to vote for other candidates. Because democracy is all about self-government, the Supreme Court has made it clear that voters are constitutionally allowed to vote for any reason, including raceconscious or even racist reasons. When the government districts minority voters together, therefore, one might imagine that it is merely supporting their desire for effective representation of their interests, as they define their own interests.

The Libertarian Fantasy, however, balks at this description because it insists that people should imagine themselves as generic autonomous choosers, not as members of groups in pluralist politics. When government districts minority voters together, it sends the message that these voters are politically defined by their race. As long as government behaves in this way, we will have racial politics. Instead, government should district blind, grouping people randomly together without regard for their race. ${ }^{20}$ As we have seen, random districting will result in

19. For European readers, nevertheless, some thumbnail descriptions might help. In this view, affirmative action is not really an effort to remedy injustice; instead, it is rent-seeking by racial minorities. Tax relief for the poor is not really an effort at economic equity; instead, it is class warfare. Multicultural education is not a good faith attempt to present the many ways of living in the world and to teach respect for others; instead, it is special pleading for locally powerful minorities. Federal protection for Native American tribal governments is not an attempt to promote the self-determination of peoples; instead, it is a denial of the American dream of limitless individual mobility. Ronald Reagan once said, revealingly, to an audience in Russia that forcible assimilation might have been better than reservation life for Native Americans: "Maybe we should not have humored them in that, wanting to stay in that kind of primitive lifestyle. Maybe we should have said, no, come join us; be citizens along with the rest of us." Ronald Reagan, Remarks at Moscow State University (May 31, 1988), at http//www.indianz.com/news/show.asp? IDzpol/4182001-1C (last visited Feb. 28, 2005). Actually, Congress gave citizenship to all Indians in 1924, see 8 U.S.C. $\$ 1401$ (b) (2000), and many were citizens even earlier. Here we have the libertarian tension in a nutshell: government must treat people as abstract individuals, even when what they really want is the messiness of pluralist identity. Somehow they are really the same, even when they seem fond of their differences.

20. See, e.g., Holder, 512 U.S. at 903-07 (Thomas, J., concurring) (For the relevant passage, see supra note 15.). 
minority underrepresentation: as they will be a minority in almost every district, they will control the election of very few legislators. If minorities conceive of their interests in racial terms, democracy may feel like a prison to them. But the Libertarian Fantasy is unfazed by this prospect: people should not conceive of their interests in racial terms in the first place; rather, they should think of themselves as generic choosers; and if the government would only stop drawing racial lines between people, then racial thinking might disappear. ${ }^{21}$ The Libertarian Fantasy therefore promises liberty to individuals as abstract individuals, not to individuals as members of groups in the messy pluralism of American politics.

We are left then with this irony: Americans are great individualists; they resent any intrusion on the power to direct their individual lives; they come in an enormous variety of types, sizes, and styles. And yet the cost of this individualism is a discomfort with real difference in the real world. The premise of our individualism is that because we are not really different, we should all receive the same formal collection of rights. This kind of individualism promises individuation but not pluralism; it promises happy harmony between generic selves, not complex negotiation among entrenched identities. It promises, in short, escape from difference through escape from government: as long as government leaves us alone, secure in our rights as abstract individuals, then we can happily coexist, united by mutual recognition of our essential and common individuality. But woe betide America if the government should start to draw lines between people as a result of pluralist politics.

In other words, when libertarians ask courts to interpret the Constitution through a libertarian lens, they are in effect asking government to provide an escape from government into a domain where we can all be alike as individuals. This view has old roots, especially in the economic realm. Let me offer just two examples. The first is Federalist No. 10, widely regarded as the single most significant exposition of the Constitution, written contemporaneously by the Constitution's principal architect, James Madison. ${ }^{22}$ Arguing for adoption of the new constitution, Madison claimed that transferring power to the central govern-

21. In Justice Thomas' opinion, the process of creating majority minority districts "is a divisive force in a community, emphasizing differences between candidates and voters that are irrelevant." Id. at 906 (Thomas, J., concurring) (quoting Wright v. Rockefeller, 376 U.S. 52, 66 (1964) (Douglas, J., dissenting)). When the government engages in "state sponsorship of such a theory of representation ... antagonisms that relate to race ... rather than to political issues are generated." Id. at 907 (quoting Wright, 376 U.S. at 67).

22. See The Federalist No. 10 (James Madison). 
ment would protect liberty because, unlike the states, the federal government would find it hard to do anything. It would be so riven with faction that majorities would be unable to form, rendering the government inert. The federal government would therefore have the bulk of constitutional power, but it would be unable to act. The upshot is that our liberties would be safe from government control. ${ }^{23}$

To this point in his analysis, Madison had been writing in universal terms: limited government would be good for everyone, because all desire the same liberties as generic individuals. But the picture changes when he offers some examples. One of his principal concerns was that the state governments had been passing debtor relief legislation; he hoped that Congress would be unable to muster a majority to pass similar legislation. ${ }^{24}$ This issue had a particular cultural context: eastern creditors had extended credit to farmers on the frontier who were having trouble paying it back because of the depressed economy. Between these two groups, eastern creditors and western debtors, grew a profound cultural divide based in different accents, economies, geographical orientations, educations, and so forth. Madison stood firmly on the side of the creditors who resisted debt relief legislation. ${ }^{25}$ By his own terms, then, Madison was speaking for generic individuals happily coexisting outside government intrusion, but in the real world of messy pluralism, he was pleading the claim of one particular social group over another.

Madison's approach eventually grew into the "harmony of interests" school of economic thought that dominated much East Coast thinking a century ago. In this view, all individuals have the same interest in blocking government regulation because immunity from regulation will create economic liberty that benefits all alike. Both workers and employers, rich and poor, should want to keep government out of their hair. Ergo, wage and hours laws, zoning regulations, workplace safety protections, and the like should be unconstitutional. The U.S. Supreme Court case Lochner v. New York ${ }^{26}$ grew out of this philosophy. That case struck down a state law limiting the hours that bakery owners could require bakery employees to work. In rejecting the law, Justice Peckham insisted that freedom of contract benefited employers and employees in the same way be-

23. See id. at $127-28$.

24. See id. at 128.

25. See Wood, supra note 4, at 487-99.

26. 198 U.S. 45 (1905). 
cause it allowed them to work out their labor relations: "Of course the liberty of contract relating to labor includes both parties to it. The one has as much right to purchase as the other to sell his labor." 27 In this vision, employer and employee are fundamentally the same as generic individuals: they possess will, reason, and private rights, and that is all that we need to know about them. Peckham disregards differences in their bargaining power, such that employers but not employees might need government protection. Again, escape from government somehow promises escape from this sort of unsettling difference. Government has the annoying habit of noticing real world pluralism and responding to it, so it is better to confine it.

The Court has, however, subsequently rejected the doctrine in Lochner, particularly its insistence on treating all actors as generic individuals devoid of social context. In West Coast Hotel v. Parrish, ${ }^{28}$ for example, the Court upheld minimum wage laws for women, explaining:

The point that has been strongly stressed that adult employees should be deemed competent to make their own contracts was decisively met [in a much earlier case] where we pointed out the inequality in the footing of the parties.... In other words, the proprietors lay down the rules, and the laborers are practically constrained to obey them. ${ }^{29}$

Since that time, the Court has allowed the legislature to recognize that people are not merely abstract choosers but rather possess distinct social identities, by providing for pluralist power sharing-and not only in the economic sphere. It has, inter alia, permitted some affirmative action, majority minority districts, tribal self-government, progressive income taxes, labor laws, workplace safety protections, minimum wage laws, multicultural education, and so forth. In the script of the Libertarian Fantasy, the government's adoption and the court's approval of such measures are wholly predictable, providing yet more evidence that government bodies are prone to capture by pluralist rent-seekers. If only we could refrain from feeding at the public trough, we might recognize that we are really all alike.

27. Id. at 56.

28. 300 U.S. 379 (1937).

29. Id. at 393-94 (quoting Holden v. Hardy, 169 U.S. 366, 397 (1898)). 
According to the Libertarian Fantasy, because government will not allow escape from itself, the only alternative is to find escape routes without government help. In the globalization age, some of these are familiar, such as multinational corporations moving factories to countries with few protections for labor or the environment. Others are less familiar, at least to the legal establishment. On some of these escape routes, libertarians and populists find themselves walking side by side, mingling elements of their different fantasies. Some libertarians insist, for example, that the Second Amendment protects an individual's right to own firearms so as to revolt against government. Others argue that they have a right to secede from the nation as a republic of one, with a jurisdiction coextensive with its founder's property. These libertarians have thus taken the doctrines of revolution and secession, so dear to populists, and given them an individualist reading. And they imagine that in a politically fragmented future, all will benefit alike because all fundamentally desire the same thing: separation from government, even if it must be achieved by force of arms. All this might be funny but for the fact that these views are not confined to a crackpot fringe. Millions of Americans share them, including a number of libertarian academics, lawyers, and politicians. ${ }^{30}$

\section{Conclusion}

Let me return at last to the thesis of the conference. As in Europe, so in the United States, many want to develop functional representation for their interests outside of government. But in the United States, most of these people want to leave government not so as to remedy a pluralistic deficit but to escape pluralism because they associate it with intrusive government. In the United States, these devices largely grow out of an enduring ideology which posits a world of unity beyond or outside government, a world that we should recapture to the extent possible. This ideology also has connections with many other aspects of American culture: our celebration of militant patriotism, in which our differences cease; our inclination toward Christian millennialism, hankering for an innocent past and yearning for a holy future as God's appointed nation; our readiness to take up arms against each other and against other countries; and our willingness to displace bad governments, so that their people can, as an organic entity,

30. Again, for details of this fantasy, see WiLLiams, supra note 17, at 151-257. 
take power into their own hands. Commonly, when we overturn a government, we find underneath not our imagined harmony but a world of socially constructed, often deeply divisive pluralism. This discovery is always a shock; we are never ready for it, and we seldom know how to respond. And so this fantasy costs us and the rest of the world dearly.

In short, we witness a similar phenomenon on both continents-the turn from government-but as always, the social meaning of this phenomenon depends on the background culture. Obviously, I am hesitant to bring American extra-governmental devices back to American government because I think that they will only hurt pluralism. Indeed, I think that their philosophical inspiration is a desire to deny pluralism. In other words, in the United States, our challenge is not merely to find instrumental devices to allow for better representation of our pluralism; our deeper challenge is to accept the legitimacy of pluralism as such, to acknowledge that difference can be real without being threatening. And to accept the legitimacy of pluralism, we will probably also have to accept the fundamental legitimacy of government as a structure for the peaceful resolution of difference in a pluralist world. So government still lies ahead of us, as a destination, not behind us, as a return. We will have to entertain, not fantasies that evaporate difference, but hopes for friendship across difference-which, come to think of it, may be the best abiding dream of the European Union. 